\title{
Burkholderia phytofirmans PsJN reduces impact of freezing temperatures on photosynthesis in Arabidopsis thaliana
}

\section{OPEN ACCESS}

Edited by:

Stéphane Hacquard, Max Planck Institute for Plant Breeding Research, Germany

Reviewed by:

Ryohei Thomas Nakano, Max Planck Institute for Plant Breeding Research, Germany Fabien Monnet, Université d'Avignon, France

*Correspondence: Nathalie Vaillant-Gaveau, Unité de Recherche Vignes et Vins de Champagne - EA 4707,

Laboratoire de Stress, Défenses et Reproduction des Plantes, UFR Sciences Exactes et Naturelles, SFR Condorcet FR CNRS 3417, Université de Reims Champagne-Ardenne, Moulin de la Housse - Bâtiment 18, BP 1039, 51687 Reims Cedex 2,

France nathalie.vaillant-gaveau@univ-reims.fr

tThese authors have contributed equally to this work.

Specialty section: This article was submitted to Plant Biotic Interactions, a section of the journal Frontiers in Plant Science

Received: 25 June 2015 Accepted: 16 September 2015 Published: 02 October 2015

Citation:

Su $F$, Jacquard C, Villaume $S$, Michel J, Rabenoelina F, Clément $C$, Barka EA, Dhondt-Cordelier S and Vaillant-Gaveau N (2015) Burkholderia phytofirmans PSJN reduces impact of freezing temperatures on photosynthesis in Arabidopsis thaliana. Front. Plant Sci. 6:810. doi: 10.3389/fpls.2015.00810

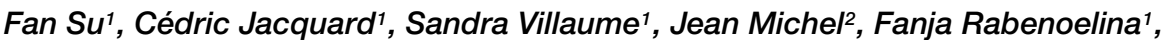 Christophe Clément ${ }^{1}$, Essaid A. Barka1 , Sandrine Dhondt-Cordelier ${ }^{1 \dagger}$ and Nathalie Vaillant-Gaveau ${ }^{1 *+}$}

${ }^{1}$ Unité de Recherche Vignes et Vins de Champagne - EA 4707, Laboratoire de Stress, Défenses et Reproduction des Plantes, UFR Sciences Exactes et Naturelles, SFR Condorcet FR CNRS 3417, Université de Reims Champagne-Ardenne, Reims, France, ${ }^{2}$ Laboratoire de Recherche en Nanosciences, Pôle Farman, Reims, France

Several plant growth-promoting rhizobacteria (PGPR) are known to improve plant tolerance to multiple stresses, including low temperatures. However, mechanisms underlying this protection are still poorly understood. The aim of this study was to evaluate the role of the endophytic PGPR, Burkholderia phytofirmans strain PSJN (Bp PSJN), on Arabidopsis thaliana cold tolerance using photosynthesis parameters as physiological markers. Under standard conditions, our results indicated that $B p$ PSJN inoculation led to growth promotion of Arabidopsis plants without significant modification on photosynthesis parameters and chloroplast organization. However, bacterial colonization induced a cell wall strengthening in the mesophyll. Impact of inoculation modes (either on seeds or by soil irrigation) and their effects overnight at $0,-1$, or $-3^{\circ} \mathrm{C}$, were investigated by following photosystem II (PSII) activity and gas exchanges. Following low temperatures stress, a decrease of photosynthesis parameters was observed. In addition, during three consecutive nights or days at $-1^{\circ} \mathrm{C}$, PSIl activity was monitored. Pigment contents, RuBisCO protein abundance, expression of several genes including RbcS, RbcL, CBF1, CBF2, CBF3, ICE1, COR15a, and COR78 were evaluated at the end of exposure. To assess the impact of the bacteria on cell ultrastructure under low temperatures, microscopic observations were achieved. Results indicated that freezing treatment induced significant changes in PSII activity as early as the first cold day, whereas the same impact on PSII activity was observed only during the third cold night. The significant effects conferred by PSJN were differential accumulation of pigments, and reduced expression of $R b c L$ and COR78. Microscopical observations showed an alteration/disorganization in A. thaliana leaf mesophyll cells independently of the freezing treatments. The presence of bacteria during the three successive nights or days did not significantly improved $A$. thaliana responses but prevented the plasmalemma disruption under freezing stress.

\section{Keywords: Burkholderia phytofirmans PsJN, cold, photosynthesis, PGPR, Arabidopsis}

Abbreviations: Bp PsJN, Burkholderia phytofirmans strain PsJN; CBF, C-repeat binding factor; Ci, intercellular $\mathrm{CO}_{2}$ concentration; COR, cold-responsive; E, transpiration rate; ETR, electron transport rate; Fv/Fm, maximum efficiency of PSII; $g_{s}$, stomatal conductance; ICE, inducer of CBF expression; PGPR, plant-growth-promoting rhizobacteria; Pn, net photosynthesis; PSII, photosystem II; RbcL, RuBisCO large subunit; RbcS, RuBisCO small subunit; RuBisCO, ribulose-1,5bisphosphate carboxylase/oxygenase; TEM, transmission electron microscopy; ФPSII, effective quantum yield of PSII. 


\section{Introduction}

Extreme environmental events such as prolonged drought, heavy rains or cold are likely to increase in the future due to climate change. Cold stress, including chilling $\left(0 \sim 10^{\circ} \mathrm{C}\right)$ and freezing $\left(<0^{\circ} \mathrm{C}\right)$ temperatures, slows plant growth and development (Rohde et al., 2004; Miura and Furumoto, 2013), causes plant death (Ruelland et al., 2009) and thus reduces crop yield (Boyer, 1982; Nagarajan and Nagarajan, 2010). Plants percept cold and reply by multiple adjustments at physiological, biochemical, and molecular levels (Theocharis et al., 2012b). These include reduced membrane fluidity (Orvar et al., 2000), ultrastructural modifications in cell components, including plastids and mitochondria (Zhang et al., 2011), transiently increased cytosolic $\mathrm{Ca}^{2+}$ levels (Ruelland et al., 2009; Fanucchi et al., 2012), reprogramming of the transcriptome and the proteome (Thomashow, 1998; Chinnusamy et al., 2007; Miura and Furumoto, 2013). Plants sense low temperatures and activate multiple transcriptional cascades, one of which involves $C B F$ and ICE1. CBF genes play important roles in cold acclimation and are regulated by multiple pathways (Thomashow, 2010). Three genes (CBF1/DREB1b, CBF2/DREB1c, and CBF3/DREB1a) have been well-studied in Arabidopsis. Their transcription is activated only a few minutes after transferring plants to low temperature (Gilmour et al., 2004; Medina et al., 2011) and is followed by induction of $C B F$ target genes, such as COR genes (Svensson et al., 2006). COR proteins may protect cells against environmental chilling stress or regulate gene expression during the adaptive response (Fowler and Thomashow, 2002).

Chloroplasts are the main organelle impacted by cold and photosynthesis is one of the traits that are rapidly affected by cold (Kratsch and Wise, 2000; Theocharis et al., 2012b). Cold exposures might affect chloroplast ultrastructure by altering chlorophyll antenna complexes (Ensminger et al., 2006) or/and modifying thylakoid structures (Hincha and Schmitt, 1992; Adam and Murthy, 2014). The restricted photosynthetic processes by cold temperatures lead to a lack of plant energy resource (Ensminger et al., 2006; Biswal et al., 2011). Chilling temperatures also led to stomatal closure in many cold-tolerant plants such as Arabidopsis (Kozlowski and Pallardy, 1979; Cornic and Ghashghaie, 1991; Wilkinson et al., 2001; Rohde et al., 2004), but not in cold-sensitive plants (Wilson, 1976; Lee et al., 1993). Stomatal closure limited leaf dehydration (Davies et al., 1982), but restricted $\mathrm{CO}_{2}$ uptake, and thus reduced photosynthetic activity. The photosynthetic activity is due to the RuBisCO activity, enzyme able to fix carbon in the chloroplast. The protein is composed of two subunits: the nuclear-encoded $R b c S$ gene and the chloroplast-encoded $R b c L$ gene. Accordingly, enzymatic activities involved in sugar synthesis slowed down during cold exposure (Hurry et al., 2000). Further, eleven proteins involved in the photosynthetic apparatus of Arabidopsis are modulated by freezing conditions (Fanucchi et al., 2012). Among them, the oxygen-evolving enhancer protein 1-1 and the RuBisCO large chain significantly accumulated. In contrast to RuBisCO, other Calvin cycle enzymes (RuBisCO activase, phosphoglycerol kinase, glyceraldehyde-3phosphate dehydrogenase, stromal fructose-1,6-bisphosphatase, ribulose-5-phosphate-3-epimerase, and phosphoribulokinase) showed significant reductions (Goulas et al., 2006). Moreover energy dissipation through non-photochemical quenching in cold condition could enhance cold acclimation and protect plants from oxidative damage (Ruelland and Zachowski, 2010). Furthermore, a concomitant rise in zeaxanthin levels was observed to protect the PSII reaction center from over-excitation (Król et al., 1999; Theocharis et al., 2012b). A reversible decrease of PSII activity by cold night was reported in grapevine inflorescence (Sawicki et al., 2012), Arabidopsis leaf (Zhang and Scheller, 2004), and tomato leaf (Liu et al., 2012). Moreover, light absorption decreases less than carbon fixation, which leads to generation of reactive oxygen species and thus, oxidative stress (Huner et al., 1998; Allen and Ort, 2001).

Plant tolerance to cold also depends on environmental regulators such as photoperiod and light quality (Thomashow, 1999; Kim et al., 2002). Wanner and Junttila (1999) have argued that light was required for cold acclimation in plants. These cold-adaptive processes impact photosynthesis mechanisms to re-establish cellular energy balance (Stitt and Hurry, 2002; Ensminger et al., 2006; Biswal et al., 2011).

Some bacterial strains of plant rhizosphere induced beneficial effect on plant growth (Kloepper et al., 1989, 2004; Glick, 1995; Mantelin and Touraine, 2004; Hayat et al., 2010). Such groups of bacteria are called PGPR and directly or indirectly promote plant growth by different mechanisms, e.g., phosphorussolubilization, $\mathrm{N}_{2}$-fixation, uptake facilitation of some soil nutrients, phytohormone production (Mantelin and Touraine, 2004; Bhattacharyya and Jha, 2012). Effects of PGPR are highly dependent on the plant-bacteria interaction (van Loon, 2007). Zhang et al. (2008) found that PGPR strain Bacillus subtilis GB03 increased chlorophyll content and photosynthetic efficiency of Arabidopsis by modulation of endogenous glucose concentration and abscisic acid signaling. PGPR could also protect plants against biotic and abiotic stresses (Yang et al., 2009) by inducing plant physical, chemical, and genetic modifications (Grover et al., 2011). Bp PsJN improves low temperature tolerance of grapevine by regulating expression of cold genes and inducing accumulation of proline, phenolic compounds and modification of carbohydrate metabolism (Ait Barka et al., 2006; Fernandez et al., 2012b; Theocharis et al., 2012a). Ait Barka et al. (2006) showed that Bp PsJN enhanced photosynthetic capacity and increased soluble sugar concentrations after chilling treatment in grapevine plantlets. Furthermore, Fernandez et al. (2012a) specified that $B p P s J N$ caused a non-stomatal limitation of photosynthesis under cold conditions.

The aim of the present work was to analyze the effect of the PGPR BP PsJN on photosynthetic-related responses of Arabidopsis thaliana to freezing stress. Firstly, impact of inoculation modes (either on seeds or by soil irrigation) and their effects overnight at $0,-1$, or $-3^{\circ} \mathrm{C}$, was investigated by following PSII activity and gas exchanges. Secondly, plants were treated by three consecutive nights or days at $-1^{\circ} \mathrm{C}$. PSII activity was monitored in real time during all treatments. Pigment contents, RuBisCO protein abundance, expression of several genes including $R b c S, R b c L, C B F 1, C B F 2, C B F 3, I C E 1, C O R 15 a$, 
and COR78 were evaluated at the end of exposure. In parallel, the impact of $B p P s J N$ inoculation on the cell structure under freezing temperatures was displayed by transmission electronic microscopy.

\section{Materials and Methods}

\section{Plant Material and Growth Conditions}

All experiments were performed on wild type A. thaliana ecotype Columbia. Seeds were sown on soil. Plants were grown in a controlled environment chamber at $20^{\circ} \mathrm{C} / 15^{\circ} \mathrm{C}$ (day/night), with $60 \%$ of relative humidity and a $12 \mathrm{~h}$ photoperiod (photosynthetically active radiation, $\mathrm{PAR}=120 \mu \mathrm{mol} \mathrm{m}-{ }^{2} \mathrm{~s}^{-1}$ ). For all of the experiments, measurements were performed on mature leaves of 5-weeks-old plants.

\section{Seed Bacterization}

Burkholderia phytofirmans strain PsJN tagged with green fluorescent protein (Sessitsch et al., 2005) was grown for $24 \mathrm{~h}$ at $28^{\circ} \mathrm{C}$ at $180 \mathrm{rpm}$ in King's B liquid medium supplemented with kanamycin and cycloheximide $\left(50 \mu \mathrm{g} \mathrm{ml}^{-1}\right)$. Bacteria were collected after centrifugation at $4500 \mathrm{~g}$ for $10 \mathrm{~min}$ and suspended in phosphate-buffered saline (PBS, $10 \mathrm{mM}, \mathrm{pH}$ 7.2). To obtain bacterial inoculum of $5.10^{8}$ colony forming units per $\mathrm{ml}$ (cfu $\mathrm{ml}^{-1}$ ), the concentration was adjusted by spectrophotometry (OD $600 \mathrm{~nm}$ ) to 0.5 (Pillay and Nowak, 1997). Arabidopsis seeds were immersed in bacterial inoculum of $5.10^{8} \mathrm{cfu} \mathrm{ml}^{-1}(\mathrm{SBp})$ or PBS for $3 \mathrm{~h}$ at $4^{\circ} \mathrm{C}$ (Mock).

\section{Cold Treatments during Three Consecutive Nights or Three Consecutive Days}

Plants (Mock, SBp) were transferred to a cold growth chamber maintained at $-1^{\circ} \mathrm{C}$ during $8 \mathrm{~h}$ of night-time $(0-8 \mathrm{~h})$ or $8 \mathrm{~h}$ of day-time $(8-16 \mathrm{~h})$ and at $20^{\circ} \mathrm{C}$ during the no freezing period. Control plants were kept at $20^{\circ} \mathrm{C}$ over the 3 days.

Immediately after the third night or day of cold treatment, leaves (Mock and SBp) were sampled in liquid nitrogen and stored at $-80^{\circ} \mathrm{C}$ until use (Supplementary Figure S1). These samples were used to evaluate pigment contents and gene expression. Three independent biological replicates were performed $(n=9)$.

\section{Chlorophyll a Fluorescence}

Photosystem II efficiency in Arabidopsis leaf was measured simultaneously during and after cold treatments with a chlorophyll fluorometer (MONITORING-PAM, Walz, Effeltrich, Germany). The MONITORING-PAM uses the repetitive saturation pulse method and provides an automatic data collection regime as described by Porcar-Castell et al. (2008). The pulses of light ( $\left.1 \mathrm{~s}, 3500 \mu \mathrm{mol} \mathrm{m} \mathrm{m}^{-2} \mathrm{~s}^{-1}\right)$ were applied every $20 \mathrm{~min}$. Saturating pulse analysis detected and calculated fluorescence parameters of leaves automatically. Measurements were recorded with WinControl-3 software (Heinz Walz $\mathrm{GmbH}$, Inc., Effeltrich, Germany). Three independent biological replicates were performed $(n=6)$.

\section{Pigment Quantification}

Chlorophyll a and b, carotenoid pigments were extracted with acetone $80 \%$ and the concentrations were determined by spectrophotometry, according to the absorbance coefficients determined by Wellburn (1994).

\section{RNA Extraction and Real-Time PCR}

RNA extraction and real-time PCR analysis were performed as described by Le Hénanff et al. (2013). For each sample, $100 \mathrm{mg}$ of leaves were ground in liquid nitrogen. Total RNA was isolated using Extract'All (Eurobio), and $1 \mu \mathrm{g}$ was used by reverse transcription using the Verso cDNA Synthesis Kit (Thermo Scientific) according to the manufacturer's instructions. The transcript levels were determined by qPCR using the CFX $96^{\mathrm{TM}}$ Real Time System (Biorad, France) and the SYBR Green Master Mix PCR kit as recommended by the manufacturer (Applied Biosystems). PCR conditions were $95^{\circ} \mathrm{C}$ for $15 \mathrm{~s}$ (denaturation) and $60^{\circ} \mathrm{C}$ for $1 \mathrm{~min}$ (annealing/extension) for 40 cycles. Traditional reference genes were evaluated with BioRad CFX MANAGER software v.3.0 (Actin2, UBQ5, UBQ10, $E F 1 \alpha$, and Tubulin2) to select a reference gene with a stable expression in all tested conditions (Hong et al., 2010). The expression stability geNorm $M$ value of $U B Q 5$ was below the critical value of 0.5 and among the lowest under stress conditions. Transcript level was calculated using the standard curve method and normalized against UBQ5 gene as an internal control. The specific primers used in this study were listed in Supplementary Table S1.

\section{Proteins Extraction and Western Blotting Analysis}

Total proteins were extracted from $0.2 \mathrm{~g}$ of leaf with $500 \mu \mathrm{L}$ cold extraction buffer $(250 \mathrm{mM}$ sorbitol, $50 \mathrm{mM}$ Tris- $\mathrm{HCl}, \mathrm{pH}$ 8.0, 2 mM EDTA, $7 \mathrm{~g} \mathrm{l}^{-1}$ PVPP, $5 \mathrm{mM}$ DTT, $1 \mathrm{mM}$ PMSF, and 1/100 Halt Protease Inhibitor Cocktail-Thermo Scientific) and centrifuged at $10000 \mathrm{~g}$ for $10 \mathrm{~min}$ at $4^{\circ} \mathrm{C}$. The supernatant was then collected and proteins were quantified by the Bradford method using bovine serum albumin as the standard (Bradford, 1976). Protein samples $(2 \mu \mathrm{g})$ were solubilized for $3 \mathrm{~min}$ at $95^{\circ} \mathrm{C}$ in Laemmli buffer (Laemmli, 1970) and separated by SDS-PAGE in $12 \%(\mathrm{w} / \mathrm{v})$ polyacrylamide gels, using Mini-protean three Cell electrophoresis equipment (Bio-Rad). Proteins were electrotransferred onto a polyvinylidene difluoride (PVDF) membrane using iBlot system (Invitrogen). Western blotting was performed according to standard procedures using rabbit anti-RbcL or RbcS antibodies (Agrisera; 1:10000) and peroxidase-coupled antirabbit IgG antibodies (Cell signaling; 1:5000). Actin (Agrisera; $1: 1000)$ was used as internal quantification control.

\section{Transmission Electron Microscopy of Arabidopsis Leaf Cell Structure}

Fresh leaves were collected after a treatment of three consecutive nights or three consecutive days. They were prepared for microscopy analysis. Samples were fixed in $1 \%$ glutaraldehyde (0.1 M phosphate buffer, v/v) at $\mathrm{pH} 7.2$ in $0.5 \%$ sucrose $(\mathrm{w} / \mathrm{v})$ and $0.2 \%$ Tween $20(\mathrm{v} / \mathrm{v})$ for $24 \mathrm{~h}$ and agitated at room temperature. After three rinses $(5 \mathrm{~min})$ in buffer, the leaves were post-fixed 
with $1 \%$ osmium tetroxide $(\mathrm{w} / \mathrm{v})$ in the buffer for $4 \mathrm{~h}$. Leaves were then rinsed three times $(5 \mathrm{~min})$ in the buffer, dehydrated in an alcohol series, transferred to acetone and embedded in Araldite. Transverse ultrathin sections ( $80 \mathrm{~nm}$ nominal thickness) were cut (Reichert Jung Ultracut E) from the Araldite-embedded block and mounted on 200 mesh copper grids. Sections were observed under a JEM2100F TEM (JEOL) without post-staining. Micrographs were recorded using an Orius 200D CCD camera (Gatan). For each stage, 10 leaves from five plants were used.

\section{Statistical Analysis}

Mann and Whitney test was used for all experiments, except for data generated by monitoring-PAM, which were analyzed by Student's test. A repeated two way analysis of variance (ANOVA) was added for data of gas exchanges and PSII activity $2 \mathrm{~h}$ after one cold night.

\section{Results}

The PGPR Bp PsJN is able to promote growth of several plants (Frommel et al., 1991; Nowak et al., 1995; Ait Barka et al., 2000; Poupin et al., 2013). In A. thaliana, Bp PsJN established root endophytic population independently of inoculation method (around $10^{4} \mathrm{cfu} \mathrm{g-}{ }^{1} \mathrm{FW}$ ), whereas, no bacteria were detected in leaves (Supplementary Figure S2). This presence in roots triggered a significant promotion of aerial plant growth compared with the mock-treated plants $(127,126$, and $128 \%$, respectively; Supplementary Figure S3).

\section{Modification of Photosynthesis during and after a Cold Night}

In order to understand if bacterial colonization and growth promotion may help plant to resist to low temperatures Photosynthetic parameters were investigated. Results showed that Fv/Fm of control plants decreased during the night (from 0.817 to 0.737 ), with a more pronounced effect during the cold night (Supplementary Figure S4A). However, the level of this decrease was dependent on the cold intensity. At 0 and $-1^{\circ} \mathrm{C}, \mathrm{Fv} / \mathrm{Fm}$ was gradually reduced during the night. Despite that applied cold temperatures were reached after $30 \mathrm{~min}$ of exposure (Supplementary Figure S4B), the shift of photosynthetical response was recorded only $60 \mathrm{~min}$ later in leaves treated at $-3^{\circ} \mathrm{C}$. The endophytic presence of $B p P s J N$ in A. thaliana has no impact on plant response to cold.

Two-way analysis of variance revealed a negative impact of cold temperatures on all tested photosynthetic parameters (Supplementary Table S2). Compared to $15^{\circ} \mathrm{C}$, exposure at 0 or $-1^{\circ} \mathrm{C}$ did not modified the $\Phi$ PSII on Arabidopsis plants (Supplementary Figure S5A). After one night at $-3^{\circ} \mathrm{C}$, ФPSII was only weakened in $B p$ plants. In addition, $\mathrm{Pn}$ was reduced for all three cold treatments, with more impact at $-3^{\circ} \mathrm{C}$ than at 0 or $-1^{\circ} \mathrm{C}$ (Supplementary Figure S5B, Supplementary Table $\mathrm{S} 2)$. The presence of $B p$ PsJN (SBp and $\mathrm{SBp}+\mathrm{Bp}$ ) increased the $\mathrm{Pn}$ after the cold night at $-3^{\circ} \mathrm{C}$. For the Mock plants, intercellular $\mathrm{CO}_{2}$ concentration decreased after the cold night at 0 or $-1^{\circ} \mathrm{C}$, but not at $-3^{\circ} \mathrm{C}$ (Supplementary Figure S5C).
Considering the $\mathrm{Pn}$ reduction by cold stress, these results suggested that 0 and $-1^{\circ} \mathrm{C}$ treatments triggered stomatal limitation to $\mathrm{Pn}$ on Arabidopsis, but $-3^{\circ} \mathrm{C}$ treatment led to a non-stomatal limitation. Bp PsJN inoculations only affected $\mathrm{Ci}$ after one night at $-3^{\circ} \mathrm{C}: \mathrm{Bp}$ and $\mathrm{SBp}+\mathrm{Bp}$ plants displayed a lower Ci compared with Mock and SBp plants. The three cold temperatures triggered a similar decrease of $g_{s}$ (Supplementary Figure S5D) and E (Supplementary Figure S5E) without impact of bacterial inoculation (Supplementary Table S2). According to reported results, the seed bacterization was selected for further investigation. In addition, only treatment at $-1^{\circ} \mathrm{C}$ was chosen since $-3^{\circ} \mathrm{C}$ was too low to be applied during three consecutive days.

\section{Impact of Three Consecutive Nights or Days at $-1^{\circ} \mathrm{C}$ PSII Activity}

Non-destructive continuous measurements of chlorophyll $a$ fluorescence were thus used as a sensitive indicator of photosynthetic performance during night treatments. The monitoring-PAM was used to follow quantum yield of PSII (YII) and ETRII each 20 min during three consecutive cold-nights or cold-days (Figure 1). During the day, YII measurements reflect the ФPSII and during the night, the Fv/Fm. The first and the second cold night did not affect Fv/Fm, but it was significantly reduced by cold during the third night. Moreover, ФPSII was not affected by cold nights (Figure 1A). However, ФPSII and Fv/Fm were significantly increased after the first cold day. But this increase was not significant after the second or third cold day of treatment (Figure 1B). Neither $\Phi$ PSII nor Fv/Fm was affected by the presence of $B p P s J N$ during the three consecutive nights or days (Figures 1A,B).

Electron transport rate II (ETRII) was not affected by the three consecutive nights at $-1^{\circ} \mathrm{C}$, whereas it decreased during the cold days. However, ETRII came back to similar level to control plant immediately after the end of cold treatment (Figures 1C,D). $B p$ PsJN colonization did not affect ETRII.

\section{Pigment Contents}

The content of photosynthetic pigments was analyzed to clarify the observed variations in the chlorophyll fluorescence.

After three nights at $-1^{\circ} \mathrm{C}$, the results report that chlorophyll ( $\mathrm{a}$ and $\mathrm{b}$ ) and carotenoid contents decreased compared to nonchilled plants (Figure 2). The presence of $B p P s J N$ induced an accumulation of both chlorophylls ( $\mathrm{a}$ and $\mathrm{b}$ ) whereas carotenoid levels were not modified independently of cold treatment.

After 3 days at $-1^{\circ} \mathrm{C}$, total chlorophyll content increased, due to an accumulation of chlorophyll b (Figures 2A-C). However, the carotenoid levels decreased in response to the cold stress (Figure 2D). The presence of $B p P s J N$ triggered a reduction in total chlorophyll content, mainly due to a decrease in chlorophyll a (Figures 2A-C). Similarly, in bacterized plants, carotenoid levels slightly decreased at $20^{\circ} \mathrm{C}$ as well as at $-1^{\circ} \mathrm{C}$ (Figure 2D).

\section{Modifications of Leaf Mesophyll Cell Ultrastructure}

The major adverse effect of cold stress in plants has been seen in terms of plasma membrane damage. Such changes induced 



FIGURE 1 | Continuous measurements of fluorescence parameter during treatments with Monitoring PAM. Real-time efficiency of PSII (YII) during three consecutive nights $(\mathbf{A})$ or days $(\mathbf{B})$ at $-1{ }^{\circ} \mathrm{C}$ and at $20^{\circ} \mathrm{C}$. Real-time electron transport rate (ETRII) of PSII during three consecutive nights (C) or days (D) at $-1^{\circ} \mathrm{C}$, and at $20^{\circ} \mathrm{C}$. Data are averages of three independent experimental replicates, each with two plants per treatment $(n=6)$. Blue bars represent cold period $\left(-1^{\circ} \mathrm{C}\right)$. No significant differences between Mock and SBp conditions was observed; asterisks $(*)$ show the period of significant differences between cold and control conditions $\left(20^{\circ} \mathrm{C}\right.$; Student's test, $\left.P<0.05\right)$.

by cold stress adversely affect the growth and development of plants. In this study, modifications of leaf mesophyll cell ultrastructure were observed to illustrate impact of cold stress. TEM observations showed an alteration/disorganization in Arabidopsis leaf mesophyll cells following freezing treatments in bacterized or control plants. The control plants $\left(20^{\circ} \mathrm{C}\right.$, Mock) exhibited organized cells (Figure 3A). Chloroplasts displayed lens-like oblong shapes, exhibited starch granules and were lined close to the plasmalemma (Figure 3A). The cold stress induced modifications of cell organization and chloroplast ultrastructure (Figures 3C or E). Both freezing treatments induced a cell wall strengthening (Figures 3C,E; Table 1). Although freezing stress during the day did not impact the granule starch content (Figures 3E,F), the cold-stressed plants under night 


\section{A}

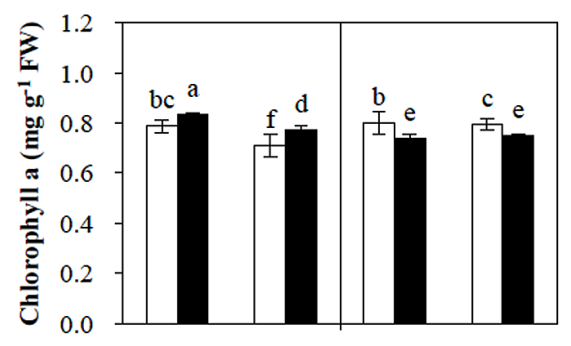

B

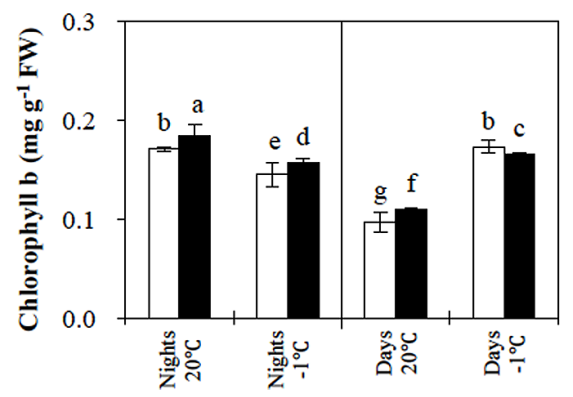

C

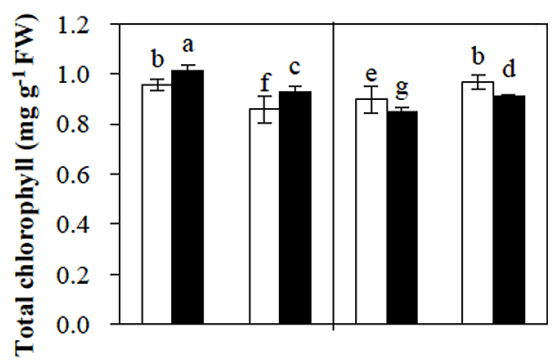

D

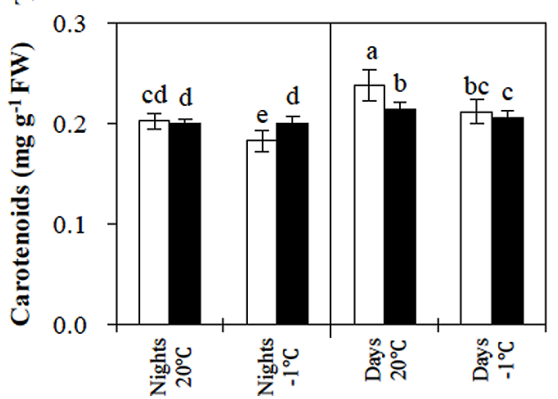

FIGURE 2 | Pigment concentration in Arabidopsis leaves of Mock and bacterized plants (SBp) after three consecutive nights or days at -1 ${ }^{\circ} \mathrm{C}$. (A) Chlorophyll a, (B) chlorophyll b, (C) total chlorophyll, and (D) carotenoids concentration. Data (mean \pm SE) are averages of three independent experimental replicates, each with three plants per treatment $(n=9)$. Same letters indicate non-significant differences among all conditions $($ Mann-Whitney test; $P<0.05)$.

condition presented chloroplast without starch granule whatever the presence of $B p P s J N$ (Figures 3C,D). Finally, some cells of stressed-plants during the night, presented a disruption of plasmalemma leading to a cell disorganization (chloroplasts and cytoplasm distant from the cell wall due to plasmalemma disruption; Figure 3C). Indeed, while no plamalemma disruption was observed in control plants, 45.8 and $48.6 \%$ of mesophyll cells exhibited disrupted membrane when cold was applied during 3 days or three nights respectively (Figure 3C; Table 2).

The TEM observations did not allowed to observe the presence of bacteria in the leaf mesophyll. At $20^{\circ} \mathrm{C}, B p P s J N$ inoculation did not modify the chloroplast organization or the presence of starch granule (Figure 3B). Interestingly, bacterized plants presented cells with strengthened cell wall compared to control plants (Table 1). The cell wall thickness of bacterized plants was similar to cold stressed plant (Figures 3B-F; Table 1). The $B p$ PsJN inoculation seemed to prevent plasmalemma disruption under freezing stress by night (Figure 3D). Indeed, cells with disturbed plasmalemma was approximately 2.5 times less abundant in bacterized-plants compared to nonbacterized plants under cold-treatment (Table 2). Nevertheless, the bacterization did not seem to impact the other effects of cold stress (Figures 3C-F).

\section{Regulation of RuBisCO}

To explore whether the difference in photosynthetic activity could be due to the RuBisCO, expression of genes encoding the two subunits of the RuBisCO (the nuclear-encoded $R b c S$ and the chloroplast-encoded $R b c L$ ) and their protein accumulation were followed. Our results showed that neither cold nor inoculation with $B p P s J N$ modified $R b c S$ expression. However,
RbcS accumulation was less pronounced in bacterized plants exposed to $-1^{\circ} \mathrm{C}$ during three consecutive nights (Figures 4B,C). For RbcL, a stronger accumulation was observed when plants were exposed to cold during the night than during the day. Bacterized plants also showed a significant reduction of $R b c L$ expression, either at $20^{\circ} \mathrm{C}$ or at $-1^{\circ} \mathrm{C}$ but such reduction in protein accumulation was only visible upon cold night exposure (Figures 4A,C).

\section{Regulation of the CBF Cold Response Pathway}

To explore whether the difference in photosynthetic activity could be correlated to a differential cold perception, cold-related marker gene expressions were analyzed before and after night or day cold stress. Expression pattern of cold genes (ICE1, CBFs, COR15a, and COR78) was monitored in mock- and Bp PsJNinoculated plants. All these genes belong to the CBF cold response pathway, which contribute to freezing tolerance (Thomashow, 2010). With the exception of ICE1, all tested genes were induced by cold treatment (Figure 5). Curiously, induction levels were higher when cold was applied during the night than during the day. Both COR genes expression were repressed during cold day treatment, but only expression of COR78 gene was repressed during cold night treatment in $B p P s J N$-inoculated plants compared with non-inoculated ones (Figures 5E,F).

\section{Discussion}

Plant growth-promoting rhizobacterias are known to induce several beneficial effects on plant growth and resistance to abiotic stresses. However, mechanisms underlying this interaction are 


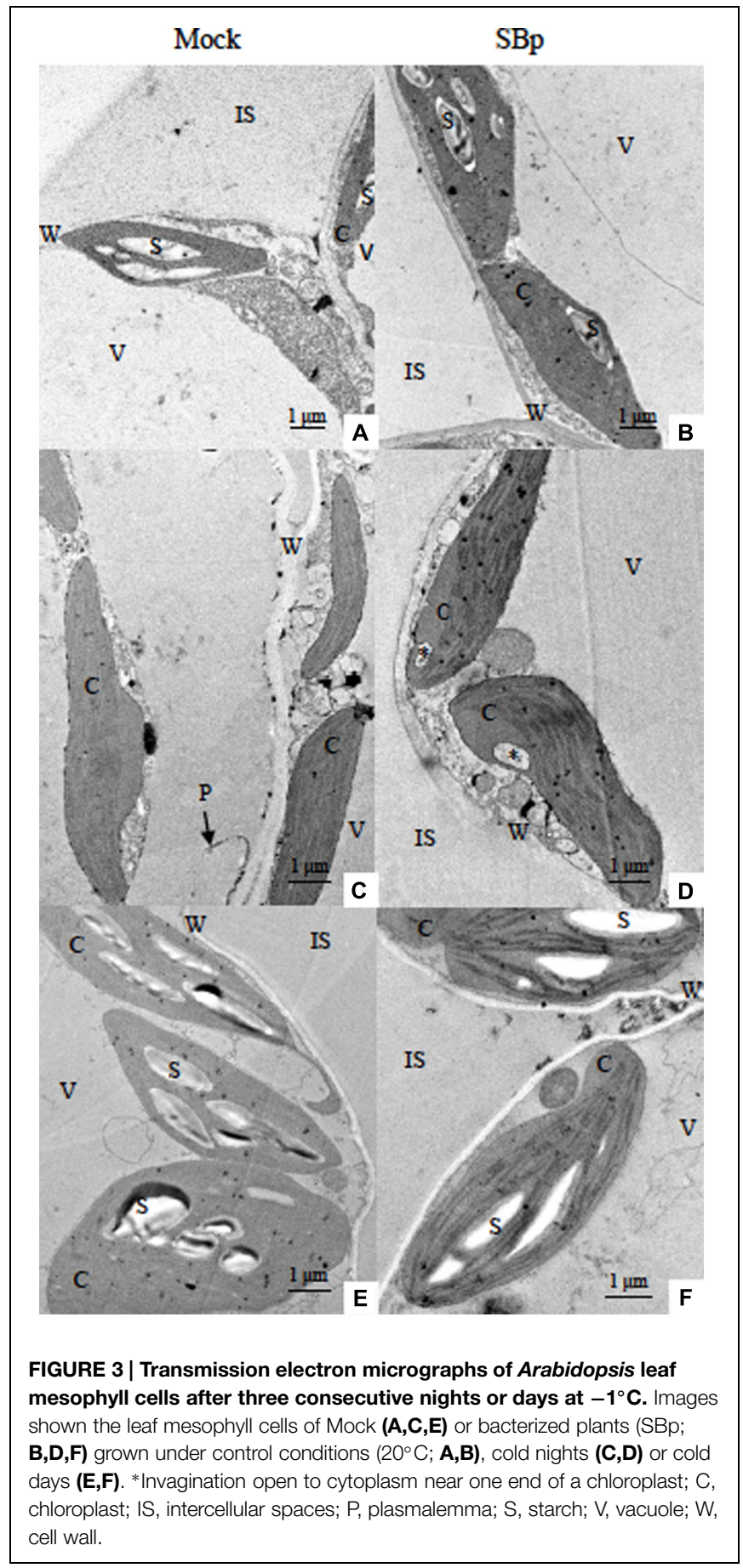

currently poorly understood. The aim of this study was to better understand how the presence of a PGPR might influence A. thaliana photosynthetic mechanisms in response to cold temperatures and thus contribute to cold acclimation.

\section{Consequences of Bp PsJN Colonization on Plant Physiology and Cell Morphology}

Our results showed that $B p P s J N$ was able to colonize $A$. thaliana roots and also to increase the plant aerial biomass. The
TABLE 1 | Impact of three consecutive nights or days at $-1^{\circ} \mathrm{C}$, or bacterial treatments on cell wall thickness with results from Mann-Whitney test.

\begin{tabular}{lccc}
\hline Treatments & $\mathbf{2 0 ^ { \circ } \mathbf { C }}$ & Nights $-\mathbf{1}^{\circ} \mathbf{C}$ & Days $-\mathbf{1}^{\circ} \mathbf{C}$ \\
\hline Mock & $0.13 \pm 0.04 \mathrm{~b}$ & $0.21 \pm 0.06 \mathrm{a}$ & $0.19 \pm 0.04 \mathrm{a}$ \\
SBp & $0.20 \pm 0.05 \mathrm{a}$ & $0.23 \pm 0.07 \mathrm{a}$ & $0.19 \pm 0.03 \mathrm{a}$ \\
\hline
\end{tabular}

Data (mean \pm SE) are average of thickness of cell wall in microns $(n=15)$. Same letters indicate non-significant differences among all conditions (Mann-Whitney test; $P<0.05)$.

TABLE 2 | Percentage of plamalemma disruption according to growth conditions in Mock and bacterized plants (SBp).

\begin{tabular}{lccc}
\hline Treatments & $\mathbf{2 0}^{\circ} \mathbf{C}$ & Nights $-\mathbf{1}^{\circ} \mathbf{C}$ & Days $-\mathbf{1}^{\circ} \mathbf{C}$ \\
\hline Mock & Oc & $45.8 \pm 11.2 \mathrm{a}$ & $48.6 \pm 11.7 \mathrm{a}$ \\
SBp & Oc & $17.9 \pm 10.9 \mathrm{~b}$ & $12.1 \pm 14.1 \mathrm{~b}$ \\
\hline
\end{tabular}

The percentages of disrupted membranes (data \pm SE) were evaluated among a total of 30 mesophyll cells.

Same letters indicate non-significant differences among all conditions (MannWhitney test; $P<0.05)$.

colonization was limited to roots systems since no bacteria were detected in Arabidopsis leaves under our conditions. In contrast, Poupin et al. (2013) mentioned that Bp PsJN might be present in aerial organ of $A$. thaliana. This discrepancy might be due probably to the different ways of bacterial inoculation and plant growth conditions.

In standard conditions, when Bp PsJN was applied either on seeds or by soil irrigation, PSII activity, gas exchanges and $\mathrm{RuBisCO}$ (gene expression and protein content) were not affected. Considering the crucial role of $\mathrm{RuBisCO}$ in carbon fixation, this result was correlated with the unchanged Pn value. However, Ait Barka et al. (2006) have reported that $B p P s J N$-inoculated grapevine plantlets exhibit a higher photosynthetic activity compared to non-bacterized plantlets. Further, switchgrass inoculation with $B p \quad P s J N$ lead to an increased photosynthetic rate without change in $\mathrm{g}_{\mathrm{s}}$ (Wang et al., 2015). In maize, $B p P s J N$ inoculation increased $g_{s}$, photosynthetic rate, photochemical efficiency of PSII and also total chlorophyll contents (Naveed et al., 2014). In Arabidopsis, enhanced plant photosynthetic capacity by B. subtilis (Zhang et al., 2008) or Bp PsJN (Poupin et al., 2013) was also associated with an enhanced chlorophyll contents. However, in $B p P s J N$-colonized grapevine plantlets, the decrease of chlorophyll contents was not associated with a ФPSII variation (Fernandez et al., 2012a). In our case, chlorophyll ( $\mathrm{a}, \mathrm{b}$ and total) contents were increased by Bp PsJN inoculation in the non-stressed leaves sampled at $8 \mathrm{~h}$, but this beneficial effect was not maintained when plants were sampled at $16 \mathrm{~h}$. Differences between the two results may be related to plant circadian rhythm, which influence transcript abundance of genes associated with chlorophyll synthesis, heme production, chlorophyll accumulation, and synthesis of chlorophyll binding proteins (Dodd et al., 2005).

In the present study, $B p P s J N$ inoculation induced a cell wall strengthening in $A$. thaliana leaf. By their presence in plant tissues, bacteria are known to induce defence mechanisms of host plants (for review: Rosenblueth and Martinez-Romero, 2006). 


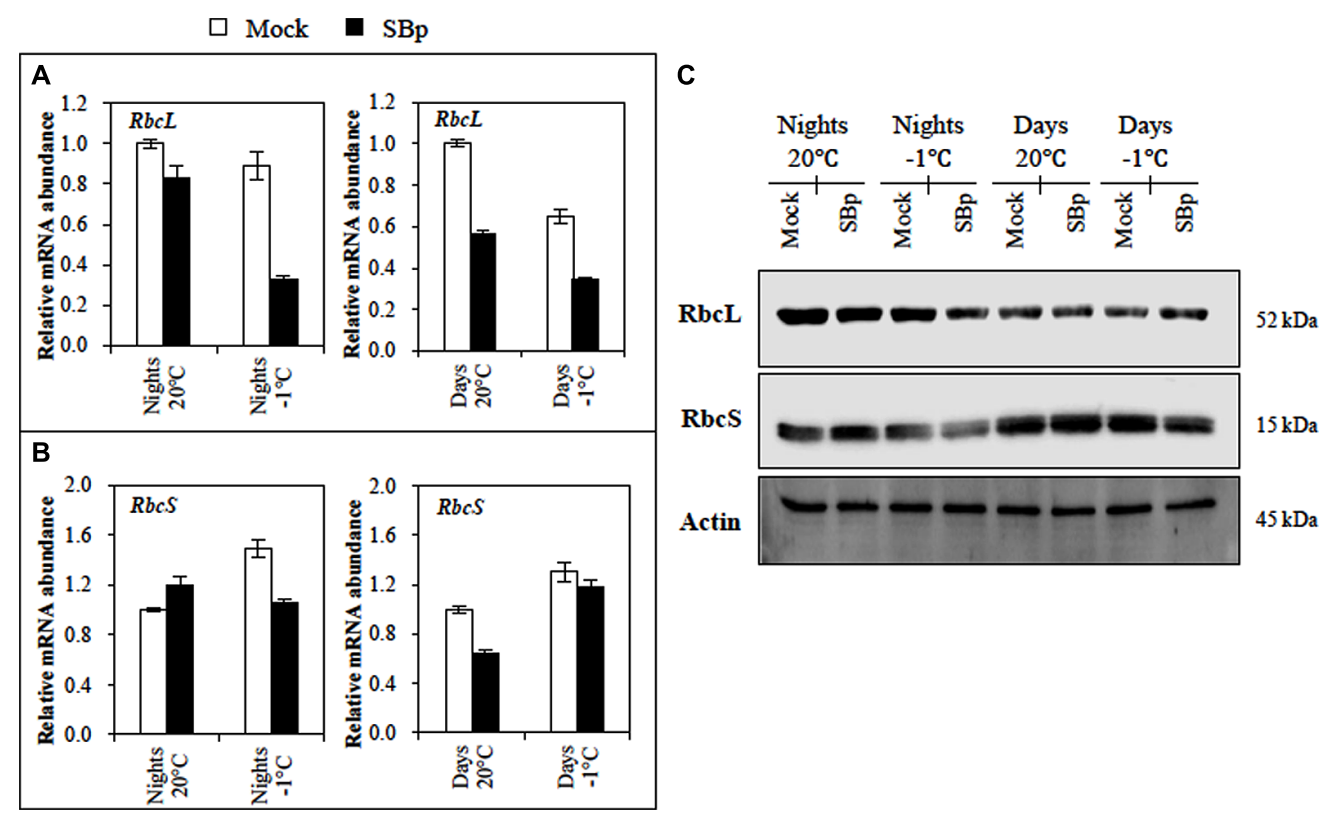

FIGURE 4 | RuBisCO regulation in Arabidopsis leaves of Mock and bacterized plants (SBp) after three consecutive nights or days at $-1^{\circ} \mathrm{C}$. Gene expression levels of RuBisCO subunit: (A) RbcL and (B) RbcS. Data (mean $\pm \mathrm{SE}$ ) represent mean fold increases in transcript level relative to those of control plants (Mock, maintained at $20^{\circ} \mathrm{C}$ ) in one representative experiment among three independent repetitions. (C) Western blots for RbcL and RbcS. Normalization was carried out with Actin. Numbers on the right indicate molecular mass in kilodaltons. Data display the results of one representative experiment among three independent repetitions.

Among the plant defence responses, the strengthening of cell walls or the establishment of surrounding material inside the xylem or the cortex have been reported (Benhamou et al., 1998, 2000; James et al., 2002; Compant et al., 2005; Miché et al., 2006). Also, Frommel et al. (1991) showed an increase of the total plant lignin content in $B p P s J N$-inoculated potato plantlets. Moreover, in grapevine plantlets, it was shown that $B p P s J N$ inoculation increases the cell wall thickness (Ait Barka et al., 2006) confirming thus our results showing that $B p P s J N$ reinforce the host cell wall.

\section{Consequences of Cold Stress}

We showed that when the stress is timely short (one night), only a temperature of $-3^{\circ} \mathrm{C}$ decreased $\mathrm{Fv} / \mathrm{Fm}$. Fv/Fm values reflect the degree of photoinhibition (Groom et al., 1991; Krivosheeva et al., 1996). When a moderate stress $\left(-1^{\circ} \mathrm{C}\right)$ was applied, three cold nights were requested to trigger photosynthesis modifications, whereas only one cold day was sufficient to induce the same modifications. A reduced Fv/Fm level by cold nights has also been reported in A. thaliana (Zhang and Scheller, 2004) and other species (Boorse et al., 1998; Hendrickson et al., 2004; Oliveira and Peñuelas, 2004; Garstka et al., 2007; Liu et al., 2012). Cold stress led to the adjustment between the capacity to harvest light energy and the capacity to consume this energy into metabolic activity in leaves (Öquist and Huner, 2003). Increases in the ratio of electron transport to $\mathrm{CO}_{2}$ assimilation have been reported in leaves under chilling conditions (Fryer et al., 1998). In accordance with Kratsch and Wise (2000), our data showed that light combined with cold temperatures may cause greater damages, as the combination can disrupt photosynthesis by photoinhibition of PSII (increase in YII and decrease in ETR). Altogether, these data imply that light greatly exacerbates chilling injury due to energy overload.

Transmission electron microscopy observations showed that freezing induced chloroplast ultrastructure disorganization, inducing large part of stroma without thylakoid. Cold damage on photosynthetic apparatus could be due to reduced lightharvesting chlorophyll contents (Król et al., 1999) and decreased functional PSII reaction centers (Ensminger et al., 2006; Savitch et al., 2010). Huner et al. (1998) showed that cold stress modified biophysical properties of thylakoid lipids causing an increase in membrane viscosity, eventually resulting in inhibition of electron transport. Following cold treatment, a plasmalemma disruption was observed leading to the cell disorganization in leaf mesophyll. This phenomenon might be due to ice formation leading to cell dehydration and may result in cell collapse (Stefanowska et al., 1999). Likewise, the enlargement of ice crystals, due to freezing stress, could generate a mechanical constraint on the cell wall and plasma membrane, leading to the cell rupture (Pearce, 1999; Mahajan and Tuteja, 2005).

The chlorophyll reduction could be associated to environmental stress responses (Hendry and Price, 1993). In parallel, increase of carotenoid is frequently related with protection mechanisms against low temperatures by avoiding photoinhibition (Demmig-Adams, 1990; Hendrickson et al., 2004). According to our results, chlorophyll and carotenoid contents decreased after three nights at $-1^{\circ} \mathrm{C}$. However, while carotenoid levels were reduced after 3 days at $-1^{\circ} \mathrm{C}$, total chlorophyll was stimulated due to a slight increase in 


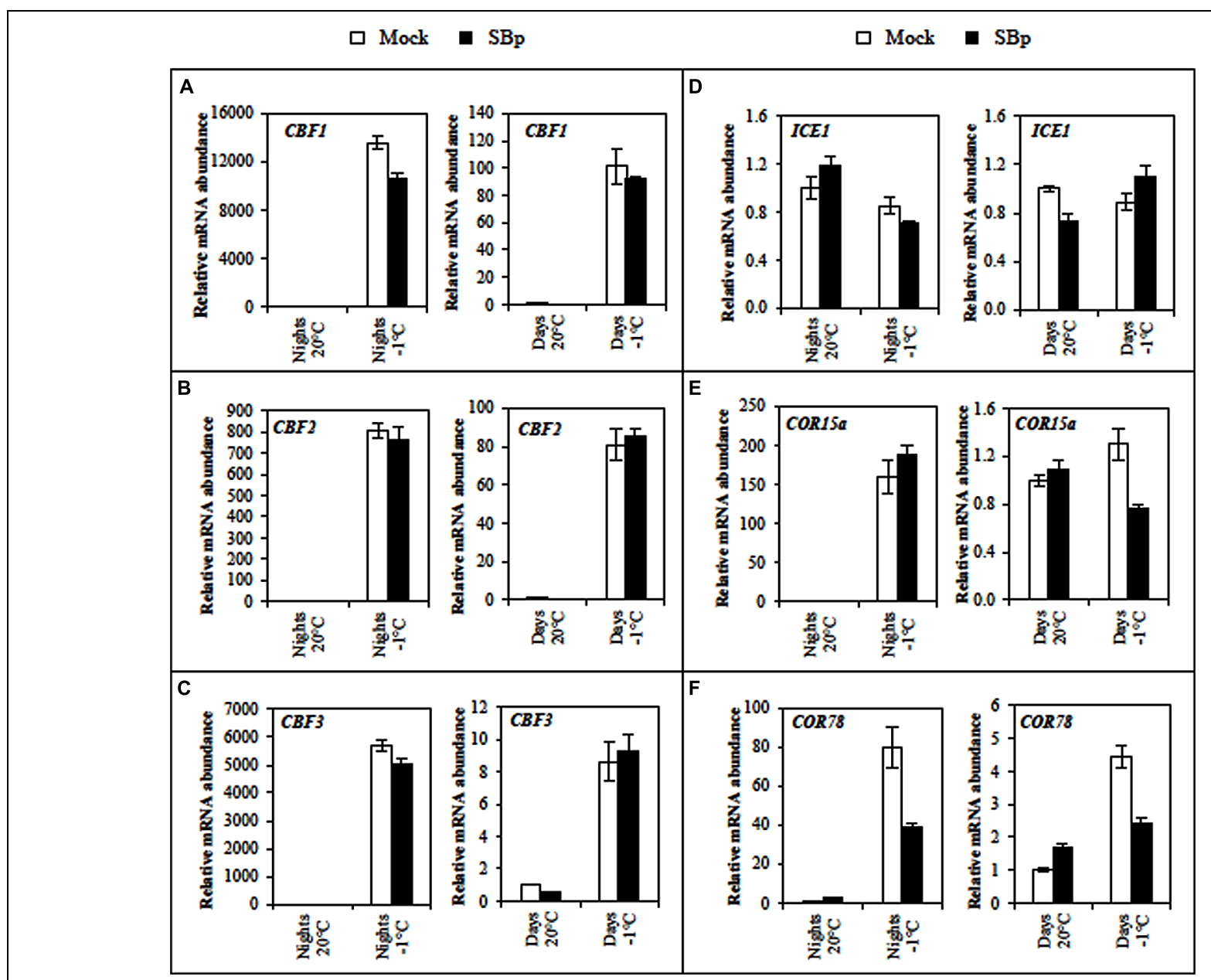

FIGURE 5 | Expression levels of the cold-induced genes (A) CBF1, (B) CBF2, (C) CBF3, (D) ICE1, (E) COR15a, and (F) COR78 in Arabidopsis leaves of Mock and bacterized plants (SBp) after three consecutive nights or days at $-\mathbf{1}^{\circ} \mathbf{C}$. Data represent mean fold increases in mRNA levels relative to those of control plants (Mock, maintained at $20^{\circ} \mathrm{C}$ ), referred to as the $\times 1$ expression level. Values shown are mean $\pm \mathrm{SE}$ of duplicate data from one representative experiment among three independent repetitions.

chlorophyll b. The observed decrease in photosynthetic pigment contents combined with disturbed chloroplast structures caused by freezing exposures might explain the reduction of PSII activity.

Plants long-term acclimation to the cold survival is intensely correlated with the recovery of photosynthesis at low temperatures (Stitt and Hurry, 2002) and the maintenance of soluble carbohydrate reserves (Olien and Clark, 1993). Considering the $\mathrm{Pn}$ reduction due to cold stress, our results suggest that one night at 0 or $-1^{\circ} \mathrm{C}$ triggered stomatal limitation of photosynthesis in $A$. thaliana, while $-3^{\circ} \mathrm{C}$ treatment led to a non-stomatal limitation. Wilkinson et al. (2001) showed that $A$. thaliana could respond to cold by stomatal closure. However, the pattern of photosynthesis limitation may depend on temperatures as described in grapevine leaves (Flexas et al., 1999) and inflorescences (Sawicki et al., 2012). Freezing temperatures could inhibit the Calvin cycle through loss of RuBisCO activity or reduction of ribulose-1,5-bisphosphate regeneration rate, resulting in a decrease of $\mathrm{Pn}$ without $\mathrm{Ci}$ decrease (Allen and Ort, 2001). In the present study, three nights at $-1^{\circ} \mathrm{C}$ slightly reduced $\mathrm{RbcS}$ contents without modifying gene expressions confirming literatures that have reported that RuBisCO protein is mainly regulated by $R b c S$ genes. In addition, in accordance with our results, Abbott and Bogorad (1987), Prioul and Reyss (1988), Piechulla (1989), have shown the low responsiveness of $R b c L$ mRNA to environmental factors. The expression of chloroplast-encoded genes, as $R b c L$, is more likely regulated at the post-transcriptional level (Mullet, 1988). Strand et al. (1999) and Hurry et al. (2000) noted that the recovery of photosynthesis and the development of freezing tolerance are strongly correlated with a reprogramming of carbon metabolism.

In this study, all three $C B F$ genes were overexpressed without modification of ICE1 expression at the end of three cold nights or days. It has been shown that cold induction of $C B F$ genes is under the control of a complex network involving ICE1 but also other transcription factors belonging to the MYB family (Theocharis et al., 2012b). In Arabidopsis, 
$C B F 1,2$, and 3 are involved in the regulation of $C O R$ gene expression and cold tolerance (Thomashow, 1999, 2010), and regulated by promoters, such as ICE1. Additionally, expression of the three $C B F$ genes in Arabidopsis could also be influenced by light quality, circadian rhythm and photoperiod (Fowler et al., 2005; Lee and Thomashow, 2012; Maibam et al., 2013). In Arabidopsis, the four major COR genes, COR6.6/KIN2, COR15A, COR47/RD17, and COR78/RD29A, encode highly hydrophilic and boiling-stable proteins that play a role in the stabilization of membranes and proteins under freeze-induced dehydration conditions (Thomashow, 1999). Our results showed that expression of COR15a and COR78 was increased only after three cold nights. Regulation of CBF target gene COR78 is slightly impacted by the circadian rhythm (Fowler et al., 2005; Medina et al., 2011). In A. thaliana, overexpression of $\mathrm{CBF} 1$ and $\mathrm{CBF} 3$ activates $\mathrm{COR}$ gene expression and enhances freezing tolerance (Liu et al., 1998; Maruyama et al., 2004).

\section{Impact of Bp PsJN during a Cold Stress}

Beneficial effects triggered by PGPR colonization against cold are associated to photosynthesis, carbohydrates and related metabolites (Ait Barka et al., 2006; Fernandez et al., 2012a,b). In this study, $B p P s J N$ inoculation did not affect PSII activity and gas exchange during and after one cold night at 0 or $-1^{\circ} \mathrm{C}$. On the opposite, the presence of Bp PsJN increased Pn after one night at $-3^{\circ} \mathrm{C}$. Considering the lower $\mathrm{Ci}$, in inoculated plants, we suggested that $B p P s J N$ enhances photosynthesis by non-stomatal mechanisms after $-3^{\circ} \mathrm{C}$ exposure. In grapevine, the presence of Bp PsJN reduces impact of chilling on Pn (Ait Barka et al., 2006; Fernandez et al., 2012a) via a non-stomatal dependent pattern (Fernandez et al., 2012a).

Bacteria $B p P s J N$ affects photosynthetic pigment accumulation and $R b c L$ gene and protein accumulation after freezing treatment. Beneficial effect was shown on chlorophyll contents after three freezing nights whereas a significant reduction of $R b c L$ expression and protein content was visible upon cold night exposure in bacterized plants. In contrast, Fernandez et al. (2012a) have shown that $B p P s J N$ presence did not modified pigment concentration (chlorophyll and carotenoid) in grapevine after 5 cold days.

Poupin et al. (2013) reported that Bp PsJN inoculation modified several gene regulations in Arabidopsis, including genes involved in defence or in biotic or abiotic stimulus responses. In grapevine, $B p P s J N$ could impact $C B F$ gene expression to enhance plant cold tolerance (Theocharis et al., 2012a). Here, the expression of COR78 gene was decreased whereas the expression of $C B F$ or ICE genes were not modified by the presence of Bp PsJN. Similarly, Xin and Browse (1998) demonstrated that esk1 (eskimo1) mutant exhibits freezing tolerance without over-expression of $C B F$ genes. Furthermore, sfr (sensitive to freezing) mutants are severely compromised in their ability to develop freezing tolerance but the regulation of $C B F / D R E B$ genes is unaffected (Knight et al., 1999). These results suggest that a pathway distinct from the $\mathrm{CBF}$ cold response pathway could be involved in freezing tolerance induced by Bp PsJN.
It is interesting to note that only expression of COR78 was repressed during cold treatment in $B p P S J N$-bacterized plants compared with mock-inoculated plants, while expression of COR15a was not impacted (only after night stress) despite that both have the same pathway. Hajela et al. (1990) reported a primary regulation at both the transcriptional (COR15a) and the post-transcriptional (COR78) levels. Similarly, differences in the tissues specificity of the promoters of these genes were reported. The COR15a promoter fused to GUS reporter gene is expressed in anthers of non-acclimated plant (Baker et al., 1994) while the COR78 promoter is not (Horvath et al., 1993). Furthermore, in cold-acclimated plants, the COR15a promoter is expressed in all flower parts except the ovary (Baker et al., 1994) while the COR78 promoter is expressed in the sepals, petals and anther filaments (Horvath et al., 1993). These funding have interesting implications regarding potential cis-acting cold-regulatory elements. Consequently, there must either be a family of cis-acting cold-regulatory elements, with each member having a different tissues specificity, and/or the cis-acting cold-regulatory elements interacts with other tissue specific elements to provide the cold regulation pattern of gene expression.

We showed that $B p P s J N$ induced a cell wall strengthening, similar to that observed following cold exposure, after either night or day-cold treatments. Previous works have shown that cold exposure increases cell wall strength and decreases the pore-size of the cell wall (Rajashekar and Lafta, 1996). Cold stress induces accumulation of cell wall components including pectin and non-cellulosic components (KubackaZebalska and Kacperska, 1999). It has been proposed that cell wall rigidity may be an important factor in cell resistance to cold stress (Rajashekar and Lafta, 1996). It was also suggested that cell wall architecture is important in plant resistance to abiotic stress (Hamann, 2012; Le Gall et al., 2015) and essential in cold-stress sensing and signal transduction (Seifert and Blaukopf, 2010). We may thus hypothesize that $B p$ PsJN could prevent freezing damages and cell collapse by inducing a cell wall strengthening. Further, the potential implication of COR genes in the stabilization of membranes and proteins under freeze-induced dehydration conditions (Thomashow, 1999) may partly explain the maintenance of cell integrity observed in the bacterized plant under low temperatures.

In the present work, we have studied the impact of the presence of $P_{s J N}$ on the tolerance of A. thaliana to low temperatures. The issue of the results indicates a strengthening of cell wall as response to the presence of $P S J N$ compared to nonbacterized plants. Moreover, after a night stress the bacteria led to better photosynthetic pigment content. We might consequently suggest that the strain $B p P s J N$ alleviate cold damages by acting on both photosynthesis and cell morphology.

\section{Author Contributions}

FS, CJ, EB, SD-C, and NV-G designed the research. FS, CJ, SV, JM, SD-C, and NV-G carried out the experiments and 
analysis/interpretation of data. FS, CJ, EB, CC, SD-C, and NV$\mathrm{G}$ wrote the manuscript with contributions and discussion from all of the co-authors. All authors have given approval to the final version of the manuscript.

\section{References}

Abbott, M.S., and Bogorad, L. (1987). "Light regulation of genes for the large and small subunits of ribulose bisphosphate carboxylase in tobacco," in Photosynthesis Research, ed. J. Biggins (Dordrecht: Springer), 527-530.

Adam, S., and Murthy, S. D. S. (2014). Characterization of alterations in photosynthetic electron transport activities in maize thylakoid membranes under zinc stress. Eur. J. Exp. Biol. 4, 25-29.

Ait Barka, E., Belarbi, A., Hachet, C., Nowak, J., and Audran, J. C. (2000). Enhancement of in vitro growth and resistance to gray mould of Vitis vinifera co-cultured with plant growth-promoting rhizobacteria. FEMS Microbiol. Lett. 186, 91-95. doi: 10.1111/j.1574-6968.2000.tb09087.x

Ait Barka, E., Nowak, J., and Clément, C. (2006). Enhancement of chilling resistance of inoculated grapevine plantlets with a plant growth-promoting rhizobacterium, Burkholderia phytofirmans strain PsJN. Appl. Environ. Microbiol. 72, 7246-7252. doi: 10.1128/AEM.01047

Allen, D. J., and Ort, D. R. (2001). Impacts of chilling temperatures on photosynthesis in warm-climate plants. Trends Plant Sci. 6, 36-42. doi: 10.1016/S1360-1385(00)01808-2

Baker, S. S., Wilhelm, K. S., and Thomashow, M. F. (1994). The 50-region of Arabidopsis thaliana cor15a has cis-acting elements that confer cold-, drought- and ABA-regulated gene expression. Plant Mol. Biol. 24, 701-713. doi: 10.1007/BF00029852

Benhamou, N., Gagné, S., Le Quéré, D., and Dehbi, L. (2000). Bacterial-mediated induced resistance in cucumber: beneficial effect of the endophytic bacterium Serratia plymuthica on the protection against infection by Pythium ultimum. Phytopathology 90, 45-56. doi: 10.1094/phyto.2000.90.1.45

Benhamou, N., Kloepper, J. W., and Tuzun, S. (1998). Induction of resistance against Fusarium wilt of tomato by combination of chitosan with an endophytic bacterial strain: ultrastructure and cytochemistry of the host response. Planta 204, 153-168. doi: 10.1007/s004250050242

Bhattacharyya, P. N., and Jha, D. K. (2012). Plant growth-promoting rhizobacteria (PGPR): emergence in agriculture. World J. Microb. Biot. 28, 1327-1350. doi: 10.1007/s11274-011-0979-9

Biswal, B., Joshi, P. N., Raval, M. K., and Biswal, U. C. (2011). Photosynthesis, a global sensor of environmental stress in green plants: stress signalling and adaptation. Curr. Sci. 101, 47-57.

Boorse, G. C., Ewers, F. W., and Davis, S. D. (1998). Response of chaparral shrubs to below-freezing temperatures: acclimation, ecotypes, seedlings vs. adults. Am. J. Bot. 85, 1224-1230. doi: 10.2307/2446631

Boyer, J. S. (1982). Plant productivity and environment. Science (N.Y.) 218, 443-448. doi: 10.1126/science.218.4571.443

Bradford, M. M. (1976). A rapid and sensitive method for the quantitation of microgram quantities of protein utilizing the principle of proteindye binding. Anal. Biochem. 72, 248-254. doi: 10.1016/0003-2697(76) 90527-3

Chinnusamy, V., Zhu, J., and Zhu, J.-K. (2007). Cold stress regulation of gene expression in plants. Trends Plant Sci. 12, 444-451. doi: 10.1016/j.tplants.2007.07.002

Compant, S., Reiter, B., Sessitsch, A., Nowak, J., Clément, C., and Ait Barka, E. (2005). Endophytic colonization of Vitis vinifera L. by Plant Growth-Promoting Bacterium Burkholderia sp. strain PsJN. Appl. Environ. Microbiol. 71, 1685-1693. doi: 10.1128/AEM.71.4.1685-1693.2005

Cornic, G., and Ghashghaie, J. (1991). Effect of temperature on net $\mathrm{CO}_{2}$ assimilation and photosystem II quantum yield of electron transfer of French bean (Phaseolus vulgaris L.) leaves during drought stress. Planta 185, 255-260. doi: $10.1007 / \mathrm{bf} 00194068$

Davies, W. J., Rodriguez, J. L., and Fiscus, E. L. (1982). Stomatal behaviour and water movement through roots of wheat plants treated with abscisic acid. Plant Cell Environ. 5, 485-493. doi: 10.1111/1365-3040. ep11611847

\section{Acknowledgment}

This work was supported by a grant from the regional program Europol'Agro (VINEAL).

Demmig-Adams, B. (1990). Carotenoids and photoprotection in plants: a role for the xanthophyll zeaxanthin. Biochim. Biophys. Acta Bioenerget. 1020, 1-24. doi: 10.1016/0005-2728(90)90088-1

Dodd, A. N., Salathia, N., Hall, A., Kevei, E., Toth, R., Nagy, F., et al. (2005). Plant circadian clocks increase photosynthesis, growth, survival, and competitive advantage. Science 309, 630-633. doi: 10.1126/science.1115581

Ensminger, I., Busch, F., and Huner, N. P. A. (2006). Photostasis and cold acclimation: sensing low temperature through photosynthesis. Physiol. Plant. 126, 28-44. doi: 10.1111/j.1399-3054.2005.00627.x

Fanucchi, F., Alpi, E., Olivieri, S., Cannistraci, C. V., Bachi, A., Alpi, A., et al. (2012). Acclimation increases freezing stress response of Arabidopsis thaliana at proteome level. Proteins Proteom. 1824, 813-825. doi: 10.1016/j.bbapap.2012.03.015

Fernandez, O., Theocharis, A., Bordiec, S., Feil, R., Jacquens, L., Clément, C., et al. (2012a). Burkholderia phytofirmans PsJN acclimates grapevine to cold by modulating carbohydrate metabolism. Am. Phytopathol. Soc. 25, 496-504.

Fernandez, O., Vandesteene, L., Feil, R., Baillieul, F., Lunn, J., and Clément, C. (2012b). Trehalose metabolism is activated upon chilling in grapevine and might participate in Burkholderia phytofirmans induced chilling tolerance. Planta 236, 355-369. doi: 10.1007/s00425-012-1611-14

Flexas, J., Escalona, J. M., and Medrano, H. (1999). Water stress induces different levels of photosynthesis and electron transport rate regulation in grapevines. Plant Cell Environ. 22, 39-48. doi: 10.1046/j.1365-3040.1999. 00371.x

Fowler, S., and Thomashow, M. (2002). Arabidopsis transcriptome profiling indicates that multiple regulatory pathways are activated during cold acclimation in addition to the CBF cold response pathway. Plant Cell 14, 1675-1690. doi: 10.1105/tpc.003483

Fowler, S. G., Cook, D., and Thomashow, M. F. (2005). Low temperature induction of Arabidopsis CBF1, 2, and 3 is gated by the circadian clock. Plant Physiol. 137, 961-968. doi: 10.1104/pp.104.058354

Frommel, M. I., Nowak, J., and Lazarovits, G. (1991). Growth enhancement and developmental modifications of in vitro grown potato (Solanum tuberosum spp. tuberosum) as affected by a non-fluorescent Pseudomonas sp. Plant Physiol. 96, 928-936. doi: 10.1104/pp.96.3.928

Fryer, M. J., Andrews, J. R., Oxborough, K., Blowers, D. A., and Baker, N. R. (1998). Relationship between $\mathrm{CO}_{2}$ assimilation, photosynthetic electron transport, and active $\mathrm{O}_{2}$ metabolism in leaves of maize in the field during periods of low temperature. Plant Physiol. 116, 571-580. doi: 10.1104/pp.116.2.571

Garstka, M., Venema, J. H., Rumak, I., Gieczewska, K., Rosiak, M., KoziolLipinska, J., et al. (2007). Contrasting effect of dark-chilling on chloroplast structure and arrangement of chlorophyll-protein complexes in pea and tomato: plants with a different susceptibility to non-freezing temperature. Planta 226, 1165-1181. doi: 10.1007/s00425-007-0562-7

Gilmour, S., Fowler, S., and Thomashow, M. (2004). Arabidopsis transcriptional activators $\mathrm{CBF} 1, \mathrm{CBF} 2$, and $\mathrm{CBF} 3$ have matching functional activities. Plant Mol. Biol. 54, 767-781. doi: 10.1023/B:PLAN.0000040902.06881.d4

Glick, B. R. (1995). The enhancement of plant growth by free-living bacteria. Can. J. Microbiol. 41, 109-117. doi: 10.1139/m95-015

Goulas, E., Schubert, M., Kieselbach, T., Kleczkowski, L. A., Gardestrom, P., Schroder, W., et al. (2006). The chloroplast lumen and stromal proteomes of Arabidopsis thaliana show differential sensitivity to short- and long-term exposure to low temperature. Plant J. 47, 720-734. doi: 10.1111/j.1365313X.2006.02821.x

Groom, Q. J., Baker, N. R., and Long, S. P. (1991). Photoinhibition of holly (Ilex aquifolium) in the field during the winter. Physiol. Plant. 83, 585-590. doi: 10.1111/j.1399-3054.1991.tb02472.x

Grover, M., Ali, S. Z., Sandhya, V., Rasul, A., and Venkateswarlu, B. (2011). Role of microorganisms in adaptation of agriculture crops to abiotic stresses. World J. Microb. Biot. 27, 1231-1240. doi: 10.1007/s11274-010-0572-7 
Hajela, R. K., Horvath, D. P., Gilmour, S. J., and Thomashow, M. F. (1990). Molecular cloning and expression of cor (cold-regulated) genes in Arabidopsis thaliana. Plant Physiol. 93, 1246-1252. doi: 10.1104/pp.93.3.1246

Hamann, T. (2012). Plant cell wall integrity maintenance as an essential component of biotic stress response mechanisms. Front. Plant Sci. 3:77. doi: 10.3389/fpls.2012.00077

Hayat, R., Ali, S., Amara, U., Khalid, R., and Ahmed, I. (2010). Soil beneficial bacteria and their role in plant growth promotion: a review. Ann. Microbiol. 60, 579-598. doi: 10.1007/s13213-010-0117-1

Hendrickson, L., Ball, M. C., Wood, J. T., Chow, W. S., and Furbank, R. T. (2004). Low temperature effects on photosynthesis and growth of grapevine. Plant Cell Environ. 27, 795-809. doi: 10.1111/j.1365-3040.2004.01184.x

Hendry, G. A. F., and Price, A. H. (1993). "Stress indicators: chlorophylls and carotenoids," in Methods in Comparative Plant Ecology, eds G. A. F. Hendry and J. P. Grime (London: Chapman \& Hall), 148-152.

Hincha, D. K., and Schmitt, J. M. (1992). "Freeze-thaw injury and cryoprotection of thylakoid membranes," in Water and Life, eds G. Somero, C. Osmond, and C. Bolis (Berlin: Springer), 316-337.

Hong, S. M., Bahn, S. C., Lyu, A., Jung, H. S., and Ahn, J. H. (2010). Identification and testing of superior reference genes for a starting pool of transcript normalization in Arabidopsis. Plant Cell Physiol. 51, 1694-1706. doi: $10.1093 / \mathrm{pcp} / \mathrm{pcq} 128$

Horvath, D. P., McLarney, B. K., and Thomashow, M. F. (1993). Regulation of Arabidopsis thaliana L. (Heyn) cor78 in response to low temperature. Plant Physiol. 103, 1047-1053. doi: 10.1104/pp.103.4.1047

Huner, N. P. A., Öquist, G., and Sarhan, F. (1998). Energy balance and acclimation to light and cold. Trends Plant Sci. 3, 224-230. doi: 10.1016/s13601385(98)01248-5

Hurry, V., Strand, A., Furbank, R., and Stitt, M. (2000). The role of inorganic phosphate in the development of freezing tolerance and the acclimatization of photosynthesis to low temperature is revealed by the pho mutants of Arabidopsis thaliana. Plant J. 24, 383-396. doi: 10.1046/j.1365313x.2000.00888.x

James, E. K., Gyaneshwar, P., Mathan, N., Barraquio, W. L., Reddy, P. M., Iannetta, P. P., et al. (2002). Infection and colonization of rice seedlings by the plant growth-promoting bacterium Herbaspirillum seropedicae Z67. Mol. Plant Microbe Interact. 15, 894-906. doi: 10.1094/MPMI.2002.15. 9.894

Kim, H. J., Kim, Y. K., Park, J. Y., and Kim, J. (2002). Light signalling mediated by phytochrome plays an important role in cold-induced gene expression through the C-repeat/dehydration responsive element (C/DRE) in Arabidopsis thaliana. Plant J. 29, 693-704. doi: 10.1046/j.1365-313X.2002.01249.x

Kloepper, J. W., Lifshitz, R., and Zablotowicz, R. M. (1989). Free-living bacterial inocula for enhancing crop productivity. Trends Biotechnol. 7, 39-44. doi: 10.1016/0167-7799(89)90057-7

Kloepper, J. W., Ryu, C.-M., and Zhang, S. (2004). Induced systemic resistance and promotion of plant growth by Bacillus spp. Phytopathology 94, 1259-1266. doi: 10.1094/phyto.2004.94.11.1259

Knight, H., Veale, E. L., Warren, G. J., and Knight, M. R. (1999). The sfr6 mutation in Arabidopsis suppresses low-temperature induction of genes dependent on the CRT/DRE sequence motif. Plant Cell 11, 875-886. doi: 10.1105/tpc.11.5.875

Kozlowski, T. T., and Pallardy, S. G. (1979). Effects of low temperature on leaf diffusion resistance of Ulmus americana and Fraxinus pennsylvanica seedlings. Can. J. Bot. 57, 2466-2470. doi: 10.1139/b79-291

Kratsch, H. A., and Wise, R. R. (2000). The ultrastructure of chilling stress. Plant Cell and Environ. 23, 337-350. doi: 10.1046/j.1365-3040.2000.00560.x

Krivosheeva, A., Tao, D.-L., Ottander, C., Wingsle, G., Dube, S., and Öquist, G. (1996). Cold acclimation and photoinhibition of photosynthesis in Scots pine. Planta 200, 296-305. doi: 10.1007/bf00200296

Król, M., Ivanov, A. G., Jansson, S., Kloppstech, K., and Huner, N. P. A. (1999). Greening under high light or cold temperature affects the level of xanthophyllcycle pigments, early light-inducible proteins, and light-harvesting polypeptides in wild-type barley and the Chlorina $\mathrm{f} 2$ mutant. Plant Physiol. 120, 193-204. doi: 10.1104/pp.120.1.193

Kubacka-Zebalska, M., and Kacperska, A. (1999). Low temperature-induced modifications of cell wall content and polysaccharide composition in leaves of winter oilseed rape (Brassica napus L. var. oleifera L.). Plant Sci. 148, 59-67. doi: 10.1016/S0168-9452(99)00122-3
Laemmli, U. K. (1970). Cleavage of structural proteins during the assembly of the head of bacteriophage T4. Nature 227, 680-685. doi: 10.1038/227680a0

Lee, C. M., and Thomashow, M. F. (2012). Photoperiodic regulation of the $\mathrm{C}$-repeat Binding Factor (CBF) cold acclimation pathway and freezing tolerance in Arabidopsis thaliana. Proc. Natl. Acad. Sci. U.S.A. 109, 15054-15059. doi: 10.1073/pnas.1211295109

Lee, T. M., Lur, H. S., and Chu, C. (1993). Role of abscisic acid in chilling tolerance of rice (Oryza sativa L.) seedlings. I. Endogenous abscisic acid levels. Plant Cell and Environ. 16, 481-490. doi: 10.1111/j.1365-3040.1993.tb00895.x

Le Gall, H., Philippe, F., Domon, J.-M., Gillet, F., Pelloux, J., and Rayon, C. (2015). Cell wall metabolism in response to abiotic stress. Plants 4, 112-166. doi: 10.3390/plants4010112

Le Hénanff, G., Profizi, C., Courteaux, B., Rabenoelina, F., Gerard, C., Clement, C., et al. (2013). Grapevine NAC1 transcription factor as a convergent node in developmental processes, abiotic stresses, and necrotrophic/biotrophic pathogen tolerance. J. Exp. Bot. 64, 4877-4893. doi: 10.1093/jxb/ert277

Liu, Q., Kasuga, M., Sakuma, Y., Abe, H., Miura, S., Yamaguchi-Shinozaki, K., et al. (1998). Two transcription factors, DREB1 and DREB2, with an EREBP/AP2 DNA binding domain separate two cellular signal transduction pathways in drought-and low-temperature-responsive gene expression, respectively, in Arabidopsis. Plant Cell 10, 1391-1406. doi: 10.1105/tpc.10.8.1391

Liu, Y. F., Qi, M. F., and Li, T. L. (2012). Photosynthesis, photoinhibition, and antioxidant system in tomato leaves stressed by low night temperature and their subsequent recovery. Plant Sci. 196, 8-17. doi: 10.1016/j.plantsci.2012. 07.005

Mahajan, S., and Tuteja, N. (2005). Cold, salinity and drought stresses: an overview. Arch. Biochem. Biophys. 444, 139-158. doi: 10.1016/j.abb.2005.10.018

Maibam, P., Nawkar, G. M., Park, J. H., Sahi, V. P., Lee, S. Y., and Kang, C. H. (2013). The influence of light quality, circadian rhythm, and photoperiod on the CBF-mediated freezing tolerance. Int. J. Mol. Sci. 14, 11527-11543. doi: 10.3390/ijms140611527

Mantelin, S., and Touraine, B. (2004). Plant growth-promoting bacteria and nitrate availability: impacts on root development and nitrate uptake. J. Exp. Bot. 55, 27-34. doi: 10.1093/jxb/erh010

Maruyama, K., Sakuma, Y., Kasuga, M., Ito, Y., Seki, M., Goda, H., et al. (2004). Identification of cold-inducible downstream genes of the Arabidopsis DREB1A/CBF3 transcriptional factor using two microarray systems. Plant J. 38, 982-993. doi: 10.1111/j.1365-313X.2004.02100.x

Medina, J., Catala, R., and Salinas, J. (2011). The CBFs: three Arabidopsis transcription factors to cold acclimate. Plant Sci. 180, 3-11. doi: 10.1016/j.plantsci.2010.06.019

Miché, L., Battistoni, F., Gemmer, S., Belghazi, M., and Reinhold-Hurek, B. (2006). Upregulation of jasmonate-inducible defense proteins and differential colonization of roots of Oryza sativa cultivars with the endophyte Azoarcus sp. Mol. Plant Microbe Interact. 19, 502-511. doi: 10.1094/MPMI-19-0502

Miura, K., and Furumoto, T. (2013). Cold signaling and cold response in plants. Int. J. Mol. Sci. 14, 5312-5337. doi: 10.3390/ijms14035312

Mullet, E. J. (1988). Chloroplast development and gene expression. Annu. Rev. Plant Physiol. Plant Mol. Biol. 39, 475-502. doi: 10.1146/annurev.pp.39.060188.002355

Nagarajan, S., and Nagarajan, S. (2010). "Abiotic tolerance and crop improvement," in Abiotic Stress Adaptation in Plants, eds A. Pareek, S. K. Sopory, H. Bohnert, and A. Gobindjee (Amsterdam: Springer), 1-11.

Naveed, M., Mitter, B., Reichenauer, T. G., Wieczorek, K., and Sessitsch, A. (2014). Increased drought stress resilience of maize through endophytic colonization by Burkholderia phytofirmans PsJN and Enterobacter sp. FD17. Environ. Exp. Bot. 97, 30-39. doi: 10.1016/j.envexpbot.2013.09.014

Nowak, J., Asiedu, S. K., and Lazarovits, G. (1995). "Enhancement of in vitro growth and transplant stress tolerance of potato and vegetable plants cocultured with a plant growth promoting rhizobacterium," in Ecophysiology and Photosynthetic In Vitro Cultures, eds F. Carre and P. Chagvardieff (Aix-enProvence: CEA), 173-180.

Olien, C. R., and Clark, J. L. (1993). Changes in soluble carbohydrate composition of barley, wheat, and rye during winter. Agron. J. 85, 21-29. doi: 10.2134/agronj1993.00021962008500010005x

Oliveira, G., and Peñuelas, J. (2004). Effects of winter cold stress on photosynthesis and photochemical efficiency of PSII of the Mediterranean Cistus albidus L. and Quercus ilex L. Plant Ecol. 175, 179-191. doi: 10.1007/s11258-005-4876-x 
Öquist, G., and Huner, N. P. (2003). Photosynthesis of overwintering evergreen plants. Аnnu. Rev. Plant Biol. 54, 329-355. doi: 10.1146/annurev.arplant.54.072402.115741

Orvar, B. L., Sangwan, V., Omann, F., and Dhindsa, R. S. (2000). Early steps in cold sensing by plant cells: the role of actin cytoskeleton and membrane fluidity. Plant J. 23, 785-794. doi: 10.1046/j.1365-313x.2000.00845.x

Pearce, R. (1999). Molecular analysis of acclimation to cold. Plant Growth Regul. 29, 47-76. doi: 10.1023/a:1006291330661

Piechulla, B. (1989). Changes of the diurnal and circadian (endogenous) mRNA oscillations of the chlorophyll $\mathrm{a} / \mathrm{b}$ binding protein in tomato leaves during altered day/night (light/dark) regimes. Plant Mol. Biol. 12, 317-327. doi: $10.1007 / \mathrm{bf} 00043209$

Pillay, V. K., and Nowak, J. (1997). Inoculum density, temperature, and genotype effects on in vitro growth promotion and epiphytic and endophytic colonization of tomato (Lycopersicon esculentum $\mathrm{L}$.) seedlings inoculated with a pseudomonad bacterium. Can. J. Microbiol. 43, 354-361. doi: 10.1139/m97-049

Porcar-Castell, A., Pfündel, E., Korhonen, J. F., and Juurola, E. (2008). A new monitoring PAM fluorometer (MONI-PAM) to study the short- and long-term acclimation of photosystem II in field conditions. Photosynth. Res. 96, 173-179. doi: 10.1007/s11120-008-9292-3

Poupin, J. M., Timmermann, T., Vega, A., Zuniga, A., and Gonzalez, B. (2013). Effects of the Plant Growth-Promoting Bacterium Burkholderia phytofirmans PsJN throughout the life cycle of Arabidopsis thaliana. PLoS ONE 8:e69435. doi: 10.1371/journal.pone.0069435

Prioul, J. L., and Reyss, A. (1988). Rapid variations in the content of the RNA of the small subunit of ribulose-1,5-bisphosphate carboxylase of mature tobacco leaves in response to localized changes in light quantity. Relationships between the activity and quantity of enzyme. Planta 174, 488-494. doi: 10.1007/BF00634477

Rajashekar, C. B., and Lafta, A. (1996). Cell-wall changes and cell tension in response to cold acclimation and exogenous abscisic acid in leaves and cell cultures. Plant Physiol. 111, 605-612.

Rohde, P., Hincha, D. K., and Heyer, A. G. (2004). Heterosis in the freezing tolerance of crosses between two Arabidopsis thaliana accessions (Columbia0 and C24) that show differences in non-acclimated and acclimated freezing tolerance. Plant J. 38, 790-799. doi: 10.1111/j.1365-313X.2004. 02080.x

Rosenblueth, M., and Martinez-Romero, E. (2006). Bacterial endophytes and their interactions with hosts. Mol. Plant Microbe Interact. 19, 827-837. doi: 10.1094/mpmi-19-0827

Ruelland, E., Vaultier, M.-N., Zachowski, A., and Hurry, V. (2009). Cold signalling and cold acclimation in plants. Adv. Bot. Res. 49, 35-150. doi: 10.1016/S00652296(08)00602-2

Ruelland, E., and Zachowski, A. (2010). How plants sense temperature. Environ. Exp. Bot. 69, 225-232. doi: 10.1016/j.envexpbot.2010.05.011

Savitch, L. V., Ivanov, A. G., Krol, M., Sprott, D. P., Öquist, G., and Huner, N. P. (2010). Regulation of energy partitioning and alternative electron transport pathways during cold acclimation of lodgepole pine is oxygen dependent. Plant Cell Physiol. 51, 1555-1570. doi: 10.1093/pcp/pcq101

Sawicki, M. L., Jeanson, E., Celiz, V., Clément, C., Jacquard, C. D., and Vaillant-Gaveau, N. (2012). Adaptation of grapevine flowers to cold involves different mechanisms depending on stress intensity. PLoS ONE 7:e46976. doi: 10.1371/journal.pone.0046976

Seifert, G. J., and Blaukopf, C. (2010). Irritable walls: the plant extracellular matrix and signaling. Plant Physiol. 153, 467-478. doi: 10.1104/pp.110.1 53940

Sessitsch, A., Coenye, T., Sturz, A. V., Vandamme, P., Ait Barka, E., Salles, J. F., et al. (2005). Burkholderia phytofirmans sp. nov., a novel plant-associated bacterium with plant-beneficial properties. Int. J. Syst. Evol. Microbiol. 55, 1187-1192. doi: 10.1099/ijs.0.63149-0

Stefanowska, M., Kuras, M., Kubacka-Zebalskan, M., and Kacperska, A. (1999). Low temperature affects pattern of leaf growth and structure of cell walls in winter oilseed rape (Brassica napus L., var. oleifera L.). Ann. Bot. 84, 313-319. doi: 10.1006/anbo.1999.0924

Stitt, M., and Hurry, V. (2002). A plant for all seasons: alterations in photosynthetic carbon metabolism during cold acclimation in Arabidopsis. Curr. Opin. Plant Biol. 5, 199-206. doi: 10.1016/S1369-5266(02)00258-3

Strand, A., Hurry, V., Henkes, S., Huner, N., Gustafsson, P., Gardeström, P., et al. (1999). Acclimation of Arabidopsis leaves developing at low temperatures.
Increasing cytoplasmic volume accompanies increased activities of enzymes in the Calvin cycle and in the sucrose-biosynthesis pathway. Plant Physiol. 119, 1387-1398.

Svensson, J. T., Crosatti, C., Campoli, C., Bassi, R., Stanca, A. M., Close, T. J., et al. (2006). Transcriptome analysis of cold acclimation in barley Albina and Xantha mutants. Plant Physiol. 141, 257-270. doi: 10.1104/pp.105.072645

Theocharis, A., Bordiec, S., Fernandez, O., Paquis, S., Dhondt-Cordelier, S., Baillieul, F., et al. (2012a). Burkholderia phytofirmans PsJN primes Vitis vinifera L. and confers a better tolerance to low nonfreezing temperatures. Mol. Plant Microbe Intract. 25, 241-249. doi: 10.1094/mpmi-05-11-0124

Theocharis, A., Clément, C., and Ait Barka, E. (2012b). Physiological and molecular changes in plants grown at low temperatures. Planta 235, 1091-1105. doi: 10.1007/s00425-012-1641-y

Thomashow, M. F. (1998). Role of cold-responsive genes in plant freezing tolerance. Plant Physiol. 118, 1-8. doi: 10.1104/pp.118.1.1

Thomashow, M. F. (1999). Plant cold acclimation: freezing tolerance genes and regulatory mechanisms. Annu. Rev. Plant Physiol. Plant Mol. Biol. 50, 571-599. doi: 10.1146/annurev.arplant.50.1.571

Thomashow, M. F. (2010). Molecular basis of plant cold acclimation: insights gained from studying the CBF cold response pathway. Plant Physiol. 154, 571-577. doi: 10.1104/pp.110.161794

van Loon, L. C. (2007). Plant responses to plant growth-promoting rhizobacteria. Eur. J. Plant Pathol. 119, 243-254. doi: 10.1007/s10658-007-9165-1

Wang, B., Mei, C., and Seiler, J. R. (2015). Early growth promotion and leaf level physiology changes in Burkholderia phytofirmans strain PsJN inoculated switchgrass. Plant Physiol. Biochem. 86, 16-23. doi: 10.1016/j.plaphy.2014.11.008

Wanner, L. A., and Junttila, O. (1999). Cold induced freezing tolerance in Arabidopsis. Plant Physiol. 120, 391-399. doi: 10.1104/pp.120.2.391

Wellburn, A. R. (1994). The spectral determination of chlorophylls a and b, as well as total carotenoids, using various solvents with spectrophotometers of different resolution. J. Plant Physiol. 144, 307-313. doi: 10.1016/S0176-1617(11) 81192-2

Wilkinson, S., Clephan, A. L., and Davies, W. J. (2001). Rapid low temperatureinduced stomatal closure occurs in cold-tolerant Commelina communis leaves but not in cold-sensitive tobacco leaves, via a mechanism that involves apoplastic calcium but not abscisic acid. Plant Physiol. 126, 1566-1578. doi: 10.1104/pp.126.4.1566

Wilson, J. M. (1976). The mechanism of chill- and drought-hardening of Phaseolus vulgaris leaves. New Phytol. 76, 257-270. doi: 10.1111/j.14698137.1976.tb01459.x

Xin, X., and Browse, J. (1998). eskimol mutants of Arabidopsis are constitutively freezing-tolerant. Proc. Natl. Acad. Sci. U.S.A. 95, 7799-7804. doi: 10.1073/pnas.95.13.7799

Yang, J., Kloepper, J. W., and Ryu, C.-M. (2009). Rhizosphere bacteria help plants tolerate abiotic stress. Trends Plant Sci. 14, 1-4. doi: 10.1016/j.tplants.2008.10.004

Zhang, H., Xie, X. T., Kim, M. S., Kornyeyev, D. A., Holaday, S., and Paré, P. W. (2008). Soil bacteria augment Arabidopsis photosynthesis by decreasing glucose sensing and abscisic acid levels in planta. Plant J. 56, 264-273. doi: 10.1111/j.1365-313X.2008.03593.x

Zhang, S., Jiang, H., Peng, S., Korpelainen, H., and Li, C. (2011). Sex-related differences in morphological, physiological, and ultrastructural responses of Populus cathayana to chilling. J. Exp. Bot. 62, 675-686. doi: 10.1093/jxb/erq306

Zhang, S., and Scheller, H. V. (2004). Photoinhibition of photosystem I at chilling temperature and subsequent recovery in Arabidopsis thaliana. Plant Cell Physiol. 45, 1595-1602. doi: 10.1093/pcp/pch180

Conflict of Interest Statement: The authors declare that the research was conducted in the absence of any commercial or financial relationships that could be construed as a potential conflict of interest.

Copyright $\odot 2015$ Su, Jacquard, Villaume, Michel, Rabenoelina, Clément, Barka, Dhondt-Cordelier and Vaillant-Gaveau. This is an open-access article distributed under the terms of the Creative Commons Attribution License (CC BY). The use, distribution or reproduction in other forums is permitted, provided the original author(s) or licensor are credited and that the original publication in this journal is cited, in accordance with accepted academic practice. No use, distribution or reproduction is permitted which does not comply with these terms. 